\title{
Uterine rupture - the current scenario in the south Assam
}

\author{
Pranoy Nath \\ Correspondence: Dr Pranoy Nath, Associate Professor, Department of Obstetrics and \\ Gynaecology, Silchar Medical College, Silchar, Assam, India; Email - drnathdas@gmail.com
}

Distributed under Creative Commons Attribution-Share Alike 4.0 International.

\begin{abstract}
Objective: To find out the incidence of complete uterine rupture in Silchar Medical College and to evaluate its causes and the assessment of maternal and perinatal outcome. Methodology: All the patients diagnosed and treated as a case of rupture uterus from June 2014 to May 2015 in the department of Obstetrics and Gynaecology in Silchar Medical College and Hospital were taken. Information of cases under study was arranged in a systematic manner in MS- Excel sheet. Appropriate statistical analysis was carried out using SPSS software. Result: There were a total of 37 cases of uterine rupture, giving an incidence of 1 in $267(0.37 \%)$. The majority of the cases were unbooked (75.65\%). Nineteen (51.35\%) ruptured occurred in unscarred uterus and 18 $(48.64 \%)$ occurred in scarred uterus. In unscarred uterus majority $68.42 \%$ ruptured is due to malpresentation leading to obstructed labour. Spontaneous ruptures were more in $4^{\text {th }}$ gravid and above $(41.17 \%)$. Rent repair with or without tubal ligation was possible in $61.25 \%$ of scar rupture, $29.4 \%$ of unscarred uterine ruptures. The need of subtotal hysterectomy was higher in unscarred uterine rupture $(64.70 \%)$. Bladder injury occurred in 3 cases where repair was done. Out of the 3 cases, 2 developed VVF and one recovered. There were $2(5.40 \%)$ maternal death. Out of 37 cases $75.67 \%$ were IUD and $16.21 \%$ were live births. There was $100 \%$ IUD in rupture of unscarred uterus. Conclusion: The timely decision to do caesarean in cases of previous scar uterus and obstructed labour can reduce the rupture rates.
\end{abstract}

Keywords: Ruptured uterus, scarred uterus, unscarred uterus, malpresentation.

Uterine rupture is a catastrophic obstetrical complication. In the developed countries the incidence has reduced. An observed shift in the aetiology from obstructed labour and multiparity is seen due to increase in the primary caesarean rates. In developing countries uterine rupture in unscarred uterus is still the dominant picture and maternal death due to rupture uterus is not uncommon. In India it still accounts for 2 to $10 \%$ of all maternal deaths. Perinatal mortality ranges from 80 to $90 \%$. In a WHO systematic review of uterine rupture worldwide found the incidence of 2.3 per 10000 births ${ }^{1}$. A study was initiated by the Federation of Obstetric and
Gynaecological Societies of India, who felt the necessity to look into the issue as to why do the Indian mothers die as a result of pregnancy and child birth with a life time risk of 6 in 1,000 compared to women of Sweden having that risk of only 1 in $17,400^{2}$. The aims of the present study were to find out the incidence of complete uterine rupture in Silchar Medical College and to evaluate its causes and the assessment of maternal and perinatal outcome.

\section{Methodology}

This prospective observational study was carried out in the department of Obstetrics and Gynaecology of

Received: 10 th April 2017. Accepted: 3 rd May 2017.

Nath P. Uterine rupture - the current scenario in the south Assam. The New Indian Journal of OBGYN. 2018; 4(2):126-29 
Silchar Medical College and Hospital, Silchar from June 2014 to May 2015. All the patients diagnosed and treated as a case of rupture uterus were taken. Data were collected by a pre- designed proforma. Rupture was labelled as complete when entire thickness of the uterine wall along with visceral peritoneum had given away. Incidence of the rupture was calculated from the total number of deliveries that had occurred in the hospital during the study period. All the babies were followed up until the time of discharge for signs of intrapartum asphyxia and other problems. Mothers were followed throughout the post operative period for evidence of sepsis, abdominal distention, temperature, abdominal wound healing. Information of cases under study was arranged in a systematic manner in MS- Excel sheet.
Table 2: Risk factors of ruptured uterus

\begin{tabular}{lll}
\hline \multicolumn{2}{l}{ Risk factors } & Number (\%) \\
\hline Scar & Previous once LSCS & $13(35.13 \%)$ \\
ruptured & Previous two LSCS & $2(5.40 \%)$ \\
& Previous myomectomy & $1(2.70 \%)$ \\
& Total & $16(43.24 \%)$ \\
Malpresentation & $13(35.13 \%)$ \\
Cephalopelvic disproportion & $4(10.81 \%)$ \\
Instrumental delivery & $2(5.54 \%)$ \\
Induction & $2(5.54 \%)$ \\
Multiparity & $36(97.29 \%)$ \\
\hline
\end{tabular}

of 1 in $267(0.37 \%)$. Out of this $19(51.35 \%)$ occurred in unscarred uterus and 18(48.64\%) occurred in scarred uterus (including the iatrogenic cases) (Table 2). Total number of caesarean section done during the period is

Appropriate statistical Table 3: Causes of rupture in relation to gravidity $\begin{array}{llllll}\text { analysis was carried out } & \text { Gravida } & \text { Cause of rupture } & \text { Chi } & \text { P }\end{array}$ using SPSS software. P- (G) Unscarred Scarred Induction/forceps Total square value

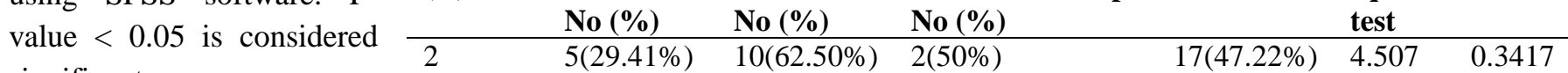
significant.

\section{Results}

$\begin{array}{lllll}3 & 5(29.41 \%) & 2(11.76 \%) & 1(25 \%) & 8(22.22 \%)\end{array}$

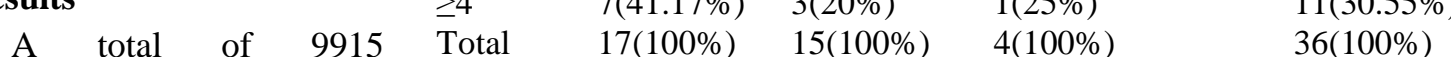
deliveries were conducted Note: G1 ( 1 case) is not included in this table during the one year period from June

Table 1: Incidence of ruptured uterus with respect to demographic variable

\begin{tabular}{lll}
\hline Demographic variables & Number (\%) \\
\hline Age in years & $20-25$ & $15(40.54 \%)$ \\
& $26-30$ & $18(48.64 \%)$ \\
& $31-35$ & $3(8.10 \%)$ \\
Residence & 36 and above & $1(2.70 \%)$ \\
& Rural & $32(86.48 \%)$ \\
Antenatal care & Urban & $5(13.51 \%)$ \\
& Booked cases & $9(24.32 \%)$ \\
Socioeconomic & Unbooked cases & $28(75.67 \%)$ \\
status & Low & $30(81.08 \%)$ \\
Parity & Middle & $7(18.91 \%)$ \\
& 0 & $1(2.70 \%)$ \\
& 1 & $18(48.64 \%)$ \\
& 2 & $7(18.91 \%)$ \\
& 3 and above & $10(27.02 \%)$ \\
\hline
\end{tabular}

2014 to May 2015. In this study period, there were 37 cases of complete uterine rupture, giving an incidence
3611, giving the incidence of $0.49 \%$ in scarred uterus. Though it was statistically not significant, the number of ruptured uterus is more in $2^{\text {nd }}$ gravid post caesarean cases and in cases of unscarred uterus it is more for women of higher parity (Table 3 ).

In this present study the commonest site of rupture was the previous caesarean scar in scarred uterus $(40.54 \%)$ and lower segment in unscarred uterus (32.43\%). The p- value has been found to be significant. Present study revealed, lower segment rupture is highest in unscarred uterus (76.92\%) (Table 4).

In the present study, rent repair with or without tubal ligation was possible in $45.94 \%$ of cases and $54.05 \%$ of cases had undergone hysterectomy. Bladder injury occurred in 3 cases where repair was done. Out of the 3 cases, 2 developed VVF and one recovered (Table 5).

In the study $40.54 \%$ of the cases had prolonged hospital stay and $24.34 \%$ had septicaemia. Two (5.40\%) developed VVF. There were $2(5.40 \%)$ maternal death 
Table 4: Site of rupture in relation to scarred and unscarred uterus

\begin{tabular}{|c|c|c|c|c|c|c|}
\hline $\begin{array}{l}\text { P- value } \\
<0.0001\end{array}$ & $\begin{array}{l}\text { Scar } \\
\text { rupture }\end{array}$ & $\begin{array}{l}\text { Lower } \\
\text { segment } \\
\text { rupture }\end{array}$ & $\begin{array}{l}\text { Upper } \\
\text { segment } \\
\text { rupture }\end{array}$ & $\begin{array}{l}\text { Lower+upper } \\
\text { segment } \\
\text { rupture }\end{array}$ & $\begin{array}{l}\text { Posterior } \\
\text { wall } \\
\text { rupture }\end{array}$ & Total \\
\hline Scarred & 15 & 2 & 0 & 1 & 0 & 18 \\
\hline Unscarred & 0 & 10 & 2 & 5 & 2 & 19 \\
\hline Total & 15 & 12 & 2 & 6 & 2 & 37 \\
\hline
\end{tabular}

Table 5: Types of management

\begin{tabular}{lll}
\hline Management & Number (\%) \\
\hline Rent repair & With sterilization & $12(32.43 \%)$ \\
& Without sterilisation & $5(13.51 \%)$ \\
& Total & $17(45.94 \%)$ \\
Hystere- & Subtotal hysterectomy & $18(48.64 \%)$ \\
ctomy & Total hysterectomy & $2(5.40 \%)$ \\
& Total & $20(54.05 \%)$ \\
Bladder repair & $3(8.10 \%)$ \\
Colporrhexis & $2(5.40 \%)$ \\
Blood transfusion & $31(83.73 \%)$ \\
\hline
\end{tabular}

from uterine rupture. There was significant number of IUD in rupture of unscarred uterus. Fetal outcome was majority referred cases $(70.27 \%)$, occurring in $2^{\text {nd }}$ gravida of low socio-economic group (81.08\%) which is similar to the other stud ies ${ }^{3-9}$.

In the Indian studies by $\mathrm{K}$. Sunitha ${ }^{3}$ and Rashmi et al ${ }^{8}$, rupture of caesarean section scar was the leading cause. But in countries like Yemen ${ }^{10}$ and Nigeria ${ }^{11}$ where family size is more, obstructed labour due to multiparity and malpresentation is the leading cause of rupture uterus. In the present study at Silchar Medical College, which reflects the population of South Assam, where family size is more, rupture of unscarred uterus is more i.e. $51.35 \%$, due to multiparity and malpresentation.

In the present study repair was possible only in $42.94 \%$ and hysterectomy was required in $54.05 \%$. This management varies with different studies. The studies done by Latika Sahu ${ }^{12}$, K. Sunitha ${ }^{3}$, Fabamwo ${ }^{13}$, Ibrahim SM ${ }^{14}$, rent repair was possible in majority of the cases i.e. $68 \%, 28.33 \%, 68.4 \%$ and $68 \%$ respectively, but in one Indian study by

Table 6: Fetal outcome in relation to cause of rupture

\begin{tabular}{lllllll}
\hline $\begin{array}{l}\text { Foetal } \\
\text { outcome }\end{array}$ & $\begin{array}{l}\text { Cause of rupture } \\
\text { Unscarred } \\
\text { No (\%) }\end{array}$ & $\begin{array}{l}\text { Scarred } \\
\text { No (\%) }\end{array}$ & $\begin{array}{l}\text { Induction/forceps } \\
\text { No(\%) }\end{array}$ & Total & $\begin{array}{l}\text { Chi } \\
\text { square } \\
\text { test }\end{array}$ & $\begin{array}{l}\text { P } \\
\text { value }\end{array}$ \\
\hline IUD & $17(100 \%)$ & $9(56.25 \%)$ & $2(50 \%)$ & $28(75.67 \%)$ & 12.746 & 0.0472 \\
Still birth & - & $1(6.25 \%)$ & - & $1(2.70 \%)$ & & \\
Live birth & - & $5(31.25 \%)$ & $1(25 \%)$ & $6(16.21 \%)$ & & \\
NICU & - & $1(6.25 \%)$ & $1(25 \%)$ & $2(5.40 \%)$ & & \\
admission & & & & & & \\
Total & $17(100 \%)$ & $16(100 \%)$ & $4(100 \%)$ & $37(100 \%)$ & & \\
\hline
\end{tabular}

Ganesh Shinde et al ${ }^{9}$ hysterectomy was performed in $64 \%$ of cases of rupture uterus. Management varies with the presence or absence of following criteria as the amount of delay in time from rupture to surgery, presence or absence of sepsis, blood loss and also with the expertise of the surgeon.

In the present study $5.40 \%$ i. e. 2 maternal deaths were recorded. There is 100\% IUD in rupture of unscarred uterus. Fetal outcome was better in cases of scar rupture. As a whole out of 37 cases $72.67 \%$ were IUD and only $21.62 \%$ were live births.

\section{Conclusion}

Uterine rupture is a devastating condition. Booking of the patients followed by a good quality antenatal care by the obstetric care provider, detection of high risk cases, timely referral with smooth and swift transportation is very important for timely intervention. The timely decision to do caesarean in cases of previous scar can reduce the rupture rates in post caesarean cases. In my 
study, the factors like lack of proper antenatal care, illiteracy and ignorance to access health care system, lack of expertise to detect high risk cases and timely referral and poor transportation all lead to an increased incidence in our College. The aim with which the NHM started functioning did not have the desired impact of touching the unreachable at the peripheral level in our region. Government should take intervention to enhance the necessary infrastructure and also improve the transportation. Educating the women and her family and also the local population is equally important to avail immediate obstetric care.

\section{Conflict of interest: None. Disclaimer: Nil.}

\section{References}

1.WHO systematic review of maternal mortality and morbidity: the prevalence of uterine rupture. BJOG: An international Journal of Obstetrics and Gynaecology. 2005; 112: 1221-28.

2.Konar H, Chakraborty AB. Maternal Mortality: A FOGSI Study (Based on Institutional Data). J Obstet Gynaecol India: 2013; 63(2): 88-95.

3.Sunitha K, Indira I, Suguna P. Clinical study of rupture uterus - assessment of maternal and fetal outcome. IOSR Journal of Dental and Medical sciences. 2015; 14(3): 39-45.

4.Sahu L. A 10 year analysis of uterine rupture at a teaching institution. J Obstet Gynecol India. 2006; 56(6): 502-6.

5.Sunitha K, Indira I, Suguna P. Clinical study of rupture uterus - assessment of maternal and fetal outcome. IOSR Journal of Dental and Medical sciences. 2015; 14(3): 39-45.

6.Ibrahim SM, Umar NI, Garba NA, Bukar M, Ibrahim HA. A reappraisal of ruptured uterus in a suburban referral hospital, north- eastern Nigeria. International Journal of Medical and Applied Sciences. 2014; 3(1): 299 - 308.

7.Kidanto HL, Mwampagatwa I, Van Roosmalen J. Uterine rupture: a retrospective analysis of causes, complications and management outcomes at Muhimbili National Hospital in Dar es Salaam, Tanzania. Tanzania Journal of Health Research. 2012; 14(3): 220-5.

8.Rashmi G, Radhakrishnan N, Vaid B, Agarwal N. Rupture uterus - changing Indian Scenerio. J Indian Med Assoc. 2001; 99(11): 634-7.

9.Shinde G, Pawar A, Jaiswal P, Jadhav B. Maternal and Perinatal Outcome of Rupture Uterus at Tertiary Care Centre. Bombay Hospital Journal. 2011; 53: 3.

10.Diab AE. Uterine rupture in Yemen. Saudi Medical Journal. 2005; 26(2):264-69.

11.Omole-Ohonsi A, Attah R. Risk factors for ruptured uterus in a developing country. Gynecol Obstetric.2011; 1(102): 2161-0932.1000102.

12.Sahu L. A 10 year analysis of uterine rupture at a teaching institution. J Obstet Gynecol India. 2006; 56(6): 502-6.

13. Fabamwo A, Akinola O, Tayo A, Akpan E. Rupture of the gravid uterus: A never - ending Obstetric Disaster! The Ikeja experience. The internet journal of Gynecology and Obstetrics. 2008; 10: 2.

14.Ibrahim SM, Umar NI, Garba NA, Bukar M, Ibrahim HA. A reappraisal of ruptured uterus in a suburban referral hospital, north- eastern Nigeria. International Journal of Medical and Applied Sciences. 2014; 3(1): 299 - 308. NACO; 2015.

\section{Pranoy Nath ${ }^{1}$}

${ }^{1}$ Associate Professor, Department of Obstetrics and Gynaecology, Silchar Medical College, Silchar, Assam, India. 